\title{
Globalisation Influences and Current forms of Construction in Belgrade (Serbia)
}

\author{
Danica STANKOVIĆ ${ }^{*}$ Milan TANIĆ, Marko NIKOLIĆ, Miomir VASOV, Branko TURNŠEK, \\ Aleksandra CVETANOVIĆ, Aleksandra RANČIĆ
}

\begin{abstract}
With the growth dynamics of consumer society, globalization and its influences in architecture are present all over the world. Developmental societies, such as Serbia today, are particularly sensitive, and cities in transition and their architecture are subject to the influence of different global trends. In this paper, new forms of construction that become dominant in the first decades of the 21 st century in Serbia and the capital city Belgrade, are investigated. Considering the actuality, frequency and scope of construction, as well as the impact on the overall social development, three characteristic forms of construction have been observed: strategic projects of reconstruction and construction, condominiums and social housing facilities. The characteristics of these forms of construction are investigated by forming a base of 24 cases from different parts of the city. By their classification, according to the particularities of the noticed subgroups, the characteristic examples are analysed and determined based on the defined set of criteria.
\end{abstract}

Keywords: architecture; condominiums; globalization; social housing

\section{INTRODUCTION}

The first two decades of the 21 st century for the countries from this region, and especially for Serbia, represent a time of renewal, consolidation, and a transformation in the spirit of European values. Serbia nowadays is lagging behind through socio-political transitional processes that are directly reflected in the way of transforming its cities, building physical structures and architecture.

Since the architect creates in a certain society in which the ruling political circumstances inevitably affect his work, architecture as "political art" and an architect are in a dependent position in relation to the procuring entity, the state or private investors [1]. For the architecture and urban planning of the cities in Serbia and Belgrade as the capital city, after significant architectural undertaking from the period of socialist construction, the first decade of the $21 \mathrm{st}$ century signifies apparent influence and realization of new forms of globalist trends. This paper deals with the study of the dominant forms of construction in Serbia during the transitional changes in the case of the current architectural practice of the city of Belgrade, in which a fifth of the country's population lives. The main aim of the study is to investigate the influences of globalisation on the current architectural practice in Belgrade and Serbia.

This topic is explored by considering the following determining aspects: (1) assessment of the historical, i.e. political context of intensification of certain forms of the construction; (2) defining of the most desirable urban zones and identification of actual realizations; (3) analysis of dominant trends from the architectural point of view (4) analysis of effects of construction on the users' living condition and sustainable urban development.

\section{HISTORICAL CIRCUMSTANCES AND ARCHITECTURE IN SERBIA}

As with most other cities in Europe and the world, the development and construction of Serbian cities and Belgrade, as the capital city, is largely the result of immediate historical circumstances. The conditions in which the country has been developing, has decisively influenced its lagging behind in the processes of urbanization, so that only in the 19th century, after the liberation from the Turks, Belgrade and the Serbian cities began to transform themselves and to receive the hallmarks of European cities, through the processes of "deorientalization" [2].

After the Second World War, a particularly important period for the development of cities in the countries of the former Yugoslavia, today's Serbia and especially Belgrade, is the time of socialist construction. The dominant phenomenon in the socialist period was the construction of new towns which gain the significance of the symbol and reflect the spirit of the socialist order [3]. The architecture of the socialist Yugoslavia followed the current modernist trends [4]. The most has been invested in the development of Belgrade as the capital, and especially in the construction of New Belgrade. New Belgrade has become a "big dormitory" with little commercial content, but with an architecture that stands out in quality [5].

In the nineties, after the break-up of Yugoslavia, the first steps in political transformation in this region were made. With the first multi-party elections, the processes of privatization of state and social property are also moving [6]. In an urban policy as "a mixture of ideology and practice under the authority of the state and the market", [7] in the processes of transition, "diversification of actors" appears [8]. However, for the choice of post-socialist reforms and in particular the privatization model, domestic researchers consider that they are a consequence of the country's political situation and its dependence on foreign political and economic influences [9].

\section{TRANSITION AND ARCHITECTURE IN THE FIRST DECADES OF THE 21ST CENTURY IN SERBIA}

The second half of the 20th century was "an epoch of transition" and its "nature is reflected in architecture" [10]. As the constant shifting of directions in architecture has not been quenching for decades, following changes in the architecture of the nineties, when post-modernist notions such as a place, context, and identity in architecture were in decline, introduces the term "super-modernism" and links to the processes of globalization in architecture [11]. 
Globalization is "a homogenizing process" [12], while there is a discussion about the dualism of globalization between "homogenization and localization", [13].

The discussed flows from the aspect of the theory of architecture are also influential and inevitably significant in the transition period for architecture in Serbia. Transition processes and the strengthening of the consumer society lead to globalization impacts in the architecture of the city of Belgrade that becomes a financial intersection, and also an attractive place to live. Based on the criteria such as actuality, scope/presence of construction and significance for the sustainable development of the city, characteristic forms of construction are selected: (1) the strategic projects of reconstruction, (2) condominiums and (3) facilities of social housing.

\subsection{The Large Strategic Projects of Reconstruction}

When it comes to launching such large-scale projects in the central city zone and investing in an extensive reconstruction and building new physical structures, a large number of researchers believe that such projects "advance the competitiveness of the city" in relation to the global environment [14]. On the other hand, extensive construction interventions are often of such a scale that they can lead to "a change in the overall image of the city", [15].

In Belgrade, for decades, in the architecturalprofessional public and on the initiative of some of the governing city structures, the possibility of descending on the coast of the Sava River, and the general connection of the city with the rivers on which it lies, was considered. Bearing in mind the volume of investments and work that such an undertaking would require, due to the need to relocate existing and neglected transport and industrial infrastructure, such ideas have regularly remained in the domain of wishes and plans for the future.

However, at the beginning of 2012, the Government of the Republic of Serbia presented to the public the project of reconstruction, that is, the proposal of a town planning solution for the regulation of the Sava River waterfront basin in the section between the two existing bridges connecting the central city zone with New Belgrade. In relation to the purpose, the realization of a number of residential and commercial buildings, as well as accompanying commercial facilities, is foreseen, including a tower, which would be in terms of height the first one in the Balkans.

\subsection{Condominiums as a Form of Housing Construction in Belgrade}

The construction of condominiums is becoming more and more popular throughout the world [16]. Since the beginning of the nineties, the condominiums have become popular throughout Central and Eastern Europe.

The term condominium leads the origin from the Latin word "con" meaning "together" and "dominium" as for having ownership of the individual and the common areas and spaces [17]. In an architectural and constructional sense, those are facilities with, for Serbia, a new type of housing that is characterized by the common use of space, such as: interior rooms (reception, staircase, basements, lavatories, laundry, garages, fitness room, room for socializing, etc.), outdoor areas and facilities (courtyard, lawns, swimming pools, playgrounds, barbecue and entertainment facilities, etc.), as well as other common lands.

The condominium form of housing gives emphasis to security, i.e., the complex contains an entrance ramp with access control room, physical security 24 hours a day, 7 days a week, electronic security (video surveillance), controlled access by way of card control, as well as a reception with the assisted alert. Such smart buildings characteristics that they possess highlight the aspect of safety that condominium offers as a type of housing [18]. Condominiums also represent a socially responsible way of living, based on the highest energy and environmental standards. For these reasons, the influence of condominiums, as places of residence, on their inhabitants is multifarious [19].

\subsection{Social Housing and Transition in Serbia}

Although on a limited scale, the construction of social housing in Serbia is one constant process in the efforts to build a socially responsible society and, at the same time, employ the domestic construction industry.

The construction of social housing is intended for different social categories, and is regulated by the Law on Social Housing ("Official Gazette of the Republic of Serbia" No. 72/2009) as "the housing of an appropriate standard provided with the support of the state to households which, for social, economic and other reasons, cannot provide apartment by market conditions". As sensitive categories that need this type of aid are also considered the following categories: student housing, housing for old people, housing for young people at the beginning of working lives and young married couples, artists, etc.

Along with other spheres of life, housing construction is in Serbia in transition processes, and for the roots, it has a socialist tradition. Later than in other Eastern European countries, the period of socialist construction of social housing ends, but the law stipulates the establishment of the "Funds for the construction of solidarity apartments", for persons without the possibility of reaching an apartment [20].

After 2000, social housing apartments were financed through various programs. Refugees and Roma families are being treated through "smaller grant programs funded through foreign donations", [21]. One of the key realized programs was implemented in seven cities in Serbia in the period from 2003-2008. In the territory of the City of Belgrade, several programs including the construction of social housing intended for sale and rent have been implemented.

\section{METHODOLOGY}

The forms of construction that represent transitional influences in the architecture of Belgrade, the strategic projects of reconstruction, condominiums, and facilities of social housing, are considered through the analysis of characteristic buildings. 
The research methods used in this study are analysis, synthesis, systematization and classification method. All colected data are systematized, classified and displayed through the tables. The main applied research procedure is based on a three-step analysis method.

In the first stage, the buildings are analyzed based on their location, the year of completion, the size of the site, form of construction, number of units, overview of all the existing facilities on the site, and its way of functioning.

In the next stage, in order to perform more comprehensive summarization and systematization of the characteristics of the selected form of construction, a system of criteria that is significant for their appearance and articulation has been established. The criteria on which the analysis was based are as follows : (1) the selected city area for the location (central city zone; wider center; wider city zone; New Belgrade; peripheral city zone); (2) level of the site occupancy/ conversion of built-up area (free site; conversion of built up area); (3) a specific type of construction from the architectural aspect (single free standing buildings; buildings in row; complexes in the shape of block; larger complexes; settlement) and (4) possible effects on the living conditions of the facility users i.e. various forms of sustainable development of the city (aspects of economic sustainability; aspects of ecological sustainability; aspects of social sustainability).

At the last stage, the SWOT analysis was conducted to estimate the advantages and disadvantages, in other terms, positive and negative points of perspective in the exploitation of the analyzed buildings.

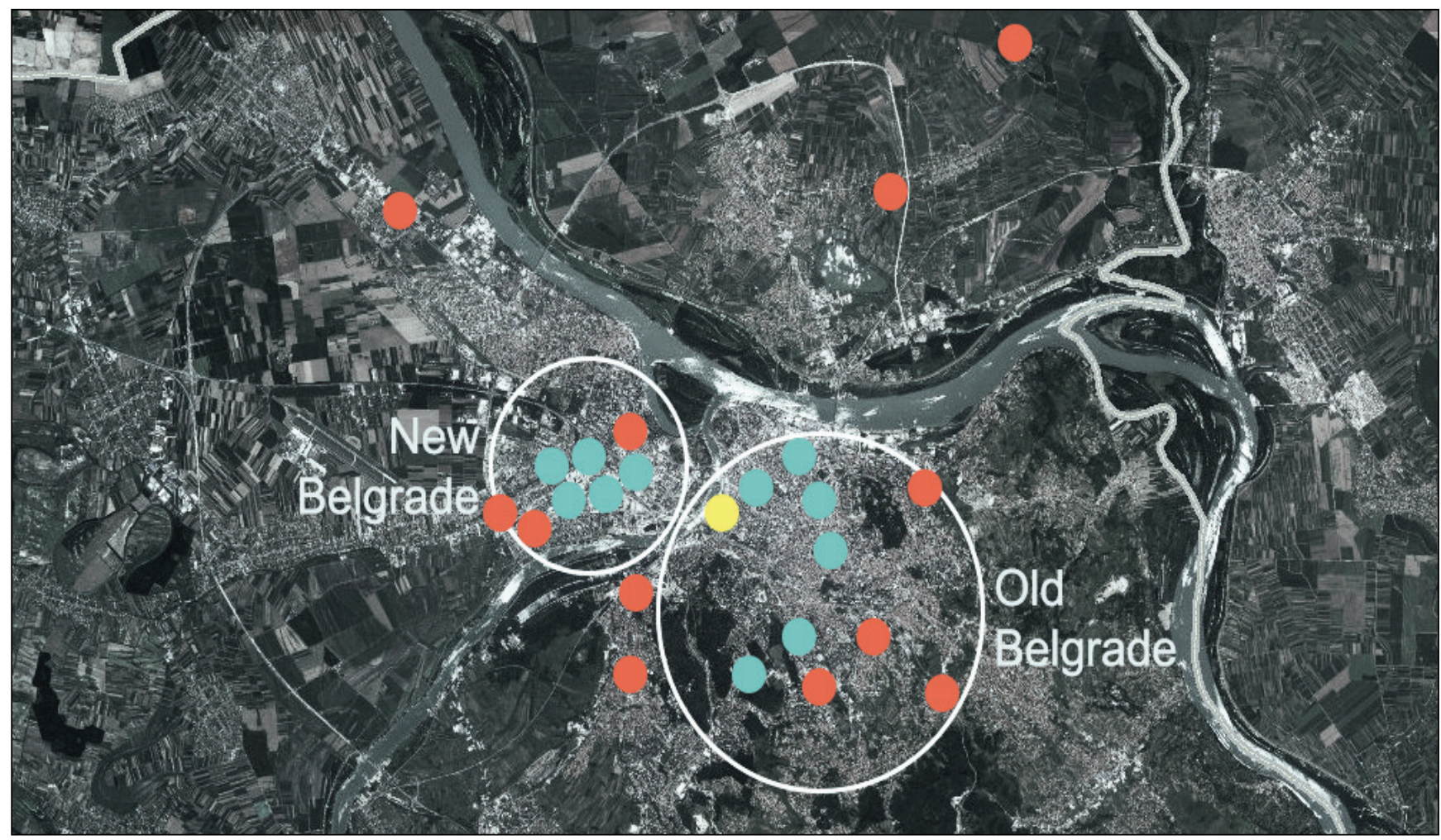

Figure 1 Map of analyzed buildings. Legend: YELLOW-Large strategic project of reconstruction, BLUE- Condominiums, RED- Social housing (Source: Authors)

\section{DESCRIPTION OF RESEARCH}

Research is defined through the analysis of the buildings and complexes which are singled out based on the defined set of criteria listed above. Considering the actuality and scope of construction, as well as the impact on the social relations, three characteristic forms of construction are observed: strategic projects of reconstruction, condominiums and social housing facilities. The characteristics of these forms of construction are investigated by forming a base of 24 cases from different parts of the city (Fig. 1). The buildings in the base are, apart from the project of reconstruction and construction of big-scale project "Belgrade Waterfront", the next condominiums: residential-business complex "Oaza"; the "Wellport" condominium; the "Green Hill" condominium; then the "Central Garden"; "The Duke's Gates"; "Kapija Vracara"; "Skyline Belgrade"; "Sky Garden"; "Airport Garden"; "AC Towers"; and "West 65
Tower and TC". The examples of social housing observed are: residential-commercial building in Block 61; the University Settlement in Block 32 and the satellite settlement in Ovca; residential-commercial Building C3 in the settlement Ivan Ribar; residential buildings in the next settlements: "Stepa Stepanovic", in Jabucki rit, in Orlovic settlement, in Veliki mokri lug, then in Padina, Kamendin, Zarkovo-Cukarica, and finally in Radnicka Street also in Cukarica.

In case of the location of the site within a certain urban zone, two categories can generally be identified: (1) the "old" part of Belgrade on the right bank of the Sava and the Danube and (2) New Belgrade. In recent years, both urban zones have been equally interesting to investors, because New Belgrade is no longer just a "sleeping area", so it cannot be said that certain type of construction is more presented in one or the other part of the city. Within the first category (1) it is possible to distinguish four cases as separate subtypes in the classification of the position of 
possible construction sites: (1a) the central city zone; (1b) wider city centre; (1c) wider city zone and (1d) the peripheral zone of the city, where it is quite understandable housing construction dominantly represented along the periphery of the city.

In relation to the degree of space occupancy that is planned for construction, the most common are two situations: (1) built sites with old and often neglected construction funds that are completely or partially out of their basic function, suitable for demolition and construction of new facilities through conversion, located in the central or wider city zones; (2) empty urban sites free for new construction, that belong to the peripheral urban zones or not completely occupied New Belgrade blocks.

Depending on the scope of the invested investments, i.e. depending on the size of the site and according to the scope of the construction, it is possible to distinguish the more represented cases. From the aspect of the architectural set of the designed buildings and their arrangement, the following types are present: (1) single free-standing buildings; (2) buildings in a row; (3) complexes in the form of a block; (4) larger complexes and (5) settlements.

Aspects of sustainability have been analyzed as the possibility of (1) economic sustainability, (2) ecological sustainability, and (3) social sustainability of certain buildings and groups.

\section{RESULTS AND DISCUSSION}

Due to the complexity of the design, the project "Belgrade Waterfront", which is at the beginning of the realization, is analyzed as a whole and viewed in the light of the designed contents. "Eagle Hills", headquartered in the United Arab Emirates, was selected as the partner in its implementation. The project represents a comprehensive intervention on the Sava waterfront, which would lead to completely redesigning the urban shape of the city of Belgrade, including a 200-meter high tower. A total construction area of the "Belgrade Waterfront" is 1.8 million $\mathrm{m}^{2}$. In relation to the purpose, the realization of 6000 residential units, $250000 \mathrm{~m}^{2}$ office space and 8 hotels, as well as accompanying commercial, cultural, educational, healthcare, recreational facilities is foreseen.

The project will provide the city to get closer to the river, where the most intense city life used to be. The construction of the first facilities began in 2014. Today, in 2019 at the planned location, a large part of the promenade along the Sava River is settled, one residential and business complex (BW Residences), is also in operation, while several multi-storeyed buildings are in the final phase, and the largest part of the overall project is in the process of preparatory work and realization.

Analyzed buildings according to their characteristics represent prominent examples of certain types of buildings (Tab. 1).

As characteristic realizations, in this research are analyzed the following condominiums: residential and business complex "Oaza" in the street of Cyril and Methodius No. 8 in Belgrade realized in 2005; the residential and commercial "Wellport" condominium in New Belgrade Block 65, the construction of which started at the end of 2018 and finished in 2019, and the residential complex "Green Hill" designed in an uninhabited natural environment in Belgrade, on Dedinje estate, finished with construction in 2018 .

Considered condominium-type of buildings, as a new form of housing, is increasingly being constructed in different parts of the city (condominium "Oaza" located in the wider center, the "Wellport" condominium located in the New Belgrade, and the "Green Hill" in the wider city zone). Positions on the site, architectural set and capacity may vary from case to case. In terms of the built area residential and business complex "Oaza" is realized on 11 $700 \mathrm{~m}^{2}$, the "Green Hill" has $11000 \mathrm{~m}^{2}$ total surface area and the "Wellport" condominium has $50000 \mathrm{~m}^{2}$ total area. In relation to architectural set the residential and business complex "Oaza" is shaped as atrium type of buildings, the "Wellport" condominium as "wings" buildings and the "Green Hill" consists of buildings in a row, freestanding buildings and "wings" buildings. Capacity of the analysed condominiums differs from 53 apartments in complex "Oaza", 37 apartments in the "Green Hill" up to 500 apartments in the "Wellport" condominium. In terms of the accompanying facilities the condominium "Oaza" has the inner closed yard, complemental facilities and underground garage, the "Wellport" has private park, sports courts, underground garage with video surveillance, high quality technical equipment, and the "Green Hill" has underground garage. Their common characteristic is their high level of the quality of construction and furnishing.

As characteristic examples of social housing are analyzed: residential-commercial building in Jurija Gagarina Street 166a, in block 61, New Belgrade, built in 2009; residential-commercial complex the University Settlement in block 32 in New Belgrade from 2007, and non-profit social and nonprofit rental housing the satellite settlement in Ovča in the municipality of Palilula in Belgrade, where the first settling of buildings began in 2016 and still is under construction (Tab. 1).

This form of construction is characterized as a local characteristic, a socially responsible function of refugee care, primarily from the former Yugoslavian areas affected by the civil war in the 1990s, then internally displaced persons from Kosovo and Metohija, as well as the Serbian Roma populations who still need assistance in providing better living conditions. In the sense of the covered area residential-commercial building in Block 61 has $7730 \mathrm{~m}^{2}$ total built area, the University Settlement in Block 32 occupies $68600 \mathrm{~m}^{2}$ and the satellite settlement in Ovča has $149650 \mathrm{~m}^{2}$.

Social housing buildings also have different architectural sets and capacities, from larger building in a singular location, present in the case of residentialcommercial building in Bl. 61 with the capacity of 105 , atrium type of buildings in University Settlement in B1. 32 with capacity of 517 apartments, up to the satellite type settlement located in Ovca with 965 apartments. They are characterized by lower standards of construction in accordance with applicable norms in the field of social housing. According to the location, they are also present in New Belgrade, but also as a satellite settlement at the edge of the city (Tab. 2).

Based on the swot analysis, it can be concluded that the positive and negative points in all three analyzed categories are almost equal in number. Certainly, each of 
these forms of housing improves the city by organizing and embellishing it. The first two categories offer more exclusive and quality finished buildings, while, on the other hand, they require a lot of investments. The first group would lead to better domestic economic status, but would also cause many urban and socio-economic problems. In the second group, the accent is on security aspects, but there is a threat in the form of segregation and very high maintenance costs. As perhaps the greatest strength of the third group, that is, social housing, the swot analysis shows the rational organization of space and quick and affordable construction, but in this category, there is a lack of green areas and arranged space for gathering. It can be concluded that although there are many positive aspects in all three groups, there are as many negative ones (Tab. $3)$.

Table 1 Characteristic buildings (Source: Authors)

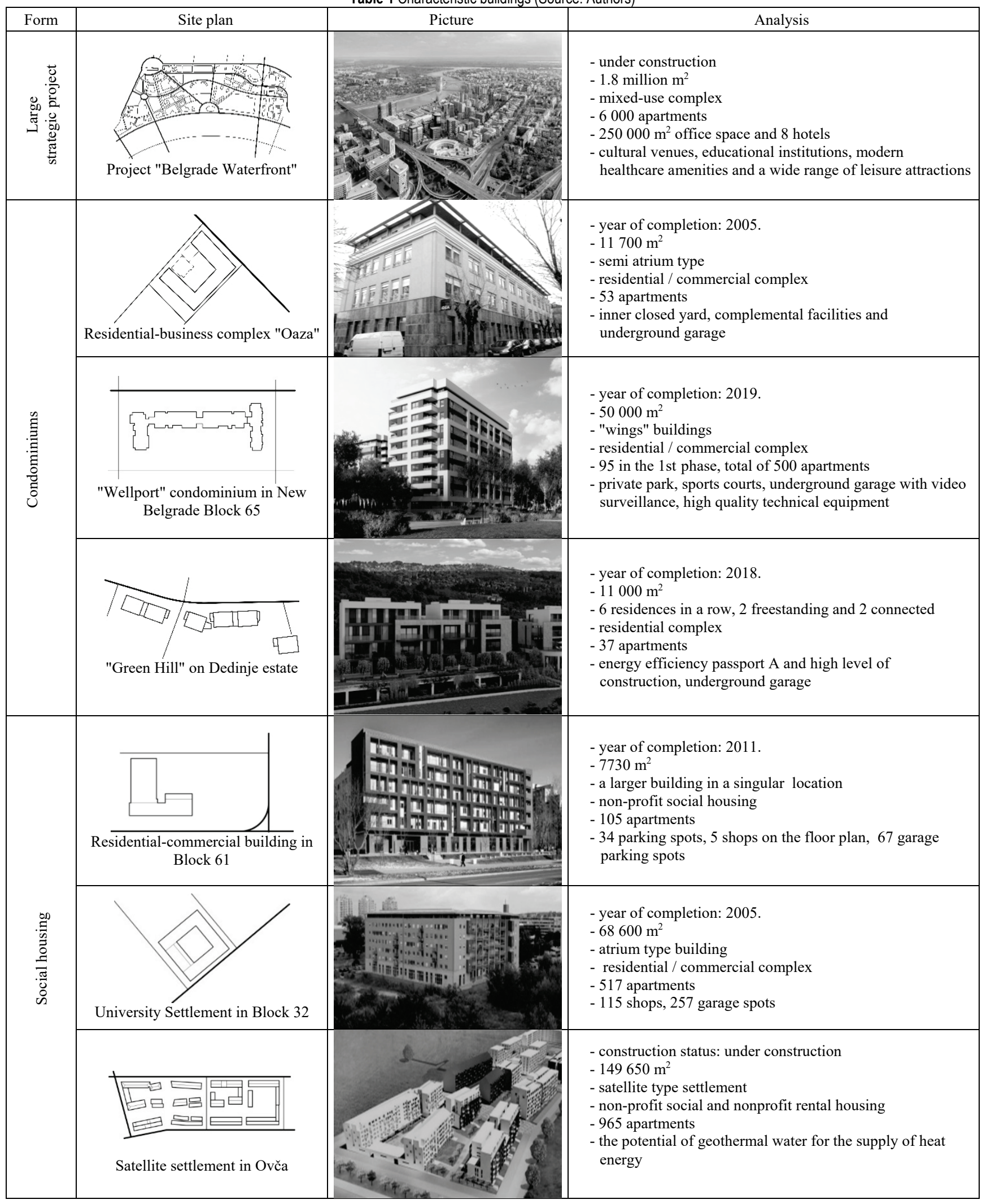




\begin{tabular}{|c|c|c|c|c|c|c|c|c|c|c|c|c|c|c|c|c|}
\hline Form of construction & Analyzed buildings & $\exists$ & 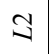 & 3 &  & 3 & $\vec{\Sigma}$ & $\mathfrak{2}$ & $E$ & E & 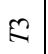 & Z & $n$ & $\overline{5}$ & $\tilde{\Sigma}$ & $\hat{n}$ \\
\hline Strategic project & "Belgrade Waterfront" & $\mathrm{X}$ & & & & & & $\mathrm{X}$ & & & & $\mathrm{X}$ & & $\mathrm{X}$ & $\mathrm{X}$ & \\
\hline \multirow{3}{*}{ Condominiums } & "Oaza" & & $\mathrm{X}$ & & & & & $\mathrm{X}$ & & & $\mathrm{X}$ & & & $\mathrm{X}$ & $\mathrm{X}$ & \\
\hline & "Wellport" & & & & $\mathrm{X}$ & & $\mathrm{X}$ & & $\mathrm{X}$ & & & & & $\mathrm{X}$ & $\mathrm{X}$ & \\
\hline & "Green Hill" & & & $\mathrm{X}$ & & & $\mathrm{X}$ & & & $\mathrm{X}$ & & & & $\mathrm{X}$ & $\mathrm{X}$ & \\
\hline \multirow{3}{*}{ Social housing } & Residential-commercial building in Block 61 & & & & $\mathrm{X}$ & & $\mathrm{X}$ & & $\mathrm{X}$ & & & & & & & $\mathrm{X}$ \\
\hline & University Settlement in Block 32 & & & & $\mathrm{X}$ & & $\mathrm{X}$ & & & & $\mathrm{X}$ & & & & & $\mathrm{X}$ \\
\hline & Satellite settlement in Ovca & & & & & $\mathrm{X}$ & $\mathrm{X}$ & & & & & & $X$ & & & \\
\hline
\end{tabular}

Legend: $L 1$ - central city zone; $L 2$ - wider center; $L 3$ - wider city zone; $L 4$ - New Belgrade; $L 5$ - peripheral city zone; $R 1$ - free site; $R 2$ - conversion of built up area; $T 1$ - single free standing buildings; $T 2$ - buildings in row; $T 3$ - complexes in the shape of block; $T 4$ - larger complexes; $T 5$ - settlement; $S 1$ - aspects of economic sustainability; $S 2$ - aspects of ecological sustainability; $S 3$ - aspects of social sustainability (Source: Authors)

Table 3 SWOT analysis (Source: Authors)

\begin{tabular}{|c|c|c|}
\hline Form of construction & \multicolumn{2}{|c|}{ Analysis } \\
\hline \multirow[b]{2}{*}{$\begin{array}{l}\text { Large } \\
\text { Strategic project } \\
\text { "Belgrade Waterfront" }\end{array}$} & $\begin{array}{l}\text { strengths } \\
\text { - site is positioned at a very prepossessing } 1.8 \text { million } \mathrm{m}^{2} \\
\text { location in a central city zone } \\
\text { - significant planning and design completed for residential } \\
\text { development of } 6000 \text { units } \\
\text { - arranged promenade along the Sava River, getting the city } \\
\text { closer to the river }\end{array}$ & $\begin{array}{l}\text { weaknesses } \\
\text { - future development design patterns are out of context } \\
\text { and in conflict with the surroundings } \\
\text { - a change in the overall identity of the city } \\
\text { - complete redesign of the urban shape of the city of } \\
\text { Belgrade }\end{array}$ \\
\hline & $\begin{array}{l}\text { opportunities } \\
\text { - the redevelopment and regeneration of the site as a mixed- } \\
\text { use complex allows for the deployment of a new identity } \\
\text { for the area } \\
\text { - instituting creative design solutions in order to minimize } \\
\text { the perception of density }\end{array}$ & $\begin{array}{l}\text { threats } \\
\text { - the need for relocating existing transport and } \\
\text { industrial infrastructure } \\
\text { - the complexity of the design } \\
\text { - urban and socio-economic segregation due to } \\
\text { exclusiveness of the development }\end{array}$ \\
\hline \multirow[b]{2}{*}{ Condominiums } & $\begin{array}{l}\text { strengths } \\
\text { - the common use of space and on-site amenities such as } \\
\text { private parks and underground garages } \\
\text { - the high degree of security given to users } \\
\text { - strong social involvement due to a smaller number of } \\
\text { apartments ( } 30-100 \text { per building) } \\
\text { - the highest energy and environmental standards }\end{array}$ & $\begin{array}{l}\text { weaknesses } \\
\text { - a high charge for the maintenance of the amenities } \\
\text { and complemental facilities } \\
\text { - restrictions and rules regarding noise levels, parking, } \\
\text { having pets, smoking, etc. }\end{array}$ \\
\hline & $\begin{array}{l}\text { opportunities } \\
\text { - better quality housing construction } \\
\text { - greater cohesion of a community } \\
\text { - creating sustainable design models with energy efficiency } \\
\text { passports }\end{array}$ & $\begin{array}{l}\text { threats } \\
\text { - creation of conditions for a high degree of social } \\
\text { segregation due to perfusion standards } \\
\text { - heterogeneity of users can lead to altercations }\end{array}$ \\
\hline \multirow{2}{*}{ Social housing } & $\begin{array}{l}\text { strengths } \\
\text { - the construction of new residential developments with } \\
\text { a larger number of apartments }(100-1000) \\
\text { - common rational organization of space } \\
\text { - application of rapid and affordable energy-efficient } \\
\text { flexible construction systems }\end{array}$ & $\begin{array}{l}\text { weaknesses } \\
\text { - common lack of green areas in the environment } \\
\text { - insufficient closed parking (ratio: } 512 \text { apartments - } \\
257 \text { garage spots) } \\
\text { - limited organized surfaces for outdoor gatherings }\end{array}$ \\
\hline & $\begin{array}{l}\text { opportunities } \\
\text { - instituting of greater uniformity of urban patterns and } \\
\text { recognizable identity } \\
\text { - inducing creative design solutions to make a sustainable } \\
\text { model } \\
\text { - social integration of users }\end{array}$ & $\begin{array}{l}\text { threats } \\
\text { - the reduced degree of social interaction and } \\
\text { intercommunication due to lack of orgnized surfaces } \\
\text { and a large number of apartments (100-1000 units) } \\
\text { - lower standards of construction }\end{array}$ \\
\hline
\end{tabular}

\section{CONCLUSION}

The first decades of the 21 st century for Serbia and Belgrade as its capital city, are the years of economic and political transition. The ruling economic and political circumstances for the situation in the field of architecture are important as an ambience with which they are in constant interaction. Thus, the development of the consumer society and the processes of society transformation towards a society with European values, in architecture and construction, activate the phenomena of globalist trends, so, apart from the presence of the universality of the architectural language in the case of the building design, for local community new and specific forms of construction on a larger scale appeared and take part in the formation of the physical structures of the city.

Three characteristic globalisation influences in the architectural practice of post-socialist Serbia are noted: launching a new strategic project to provide the city to move closer to the Sava river; then the construction of the condominiums as a new form of housing on an increasing scale, and third, social housing facilities.

In the case of the project "Belgrade Waterfront", the first positive results are seen in the regulation of the coast. The built pedestrian promenade, bicycle paths and accompanying facilities designed and materialized in contemporary way, attract the attention of a large number of users (local visitors and tourists) every day. Since most of the space and buildings are under construction, the final 
effects of the project are a big unknown for the general public and the subject of permanent discussions. This project is a proposal for urban regeneration based on the conversion of existing built land, i.e. on the displacement of outdated and neglected railway transport infrastructure in greater amount and the construction of new physical structures with residential-business, commercial and cultural facilities. The scope of the current works and construction as a result contribute to acceleration of the domestic construction industry, as well as to trafficking of the newly designed real estate. In sense of the architectural and ambiental context, the biggest challenge represents the beginning of the tower construction which will dominate by its height in the coastal area. Also, the complete architectural transformation of the regenerated coastal zone brings a new quality and also a challenge in connecting with the existing urban fabric.

A certain number of condominiums were also constructed as a conversion of the existing dysfunctional industrial heritage on locations in the wider city zone, while free site for this type of construction was mostly found in New Belgrade. The occurrence of condominiums brought high construction quality and furnishing of the living spaces, all positivity of ecologically sustainable environments, as well as the advantages of smart buildings, from the aspect of the safety and privacy of tenants.

Groups of social housing buildings and settlements are predominantly built in peripheral city zones. The standard of these apartments is at the level of normative minimum, and the danger of social segregation is at high level.

All the three analyzed forms of construction characteristic for the societies in transition are exposed to the influence of globalist processes. The specificities of the tranzitional societies, stratified and with the problems of development that exist in Serbia, contribute to the creation of the conditions for the progressive increase of the negative aspects of each form and to their more intensive manifestation. Therefore, in the case of connection of the newly constructed parts of the coastal area with the existing city zones, in the project "Belgrade Waterfront" further research should be directed towards examining the ambiental aspects, while in the field of condominiums and social housing groups special attention should be paid to researching of the social aspects.

\section{Acknowledgements}

This paper is realized within the national scientific projects at the University of Nis, financed by the Ministry of Science and Technological Development of the Republic of Serbia, No. 036045.

\section{REFERENCES}

[1] Jencks, C. (1986). Modern Movements in Architecture. Second edition, Beograd, Srbija: Gradjevinska knjiga.

[2] Göler, D. \& Lehmeier, H. (2012). From post-socialist transition to globalisation and Europeanisation? Metropolitain development in Belgrade, Bucharest and Sofia. Collection of Papers - Faculty of Geography at University of Belgrade, 60, 33-48.

[3] Kissfazekas, K. (2015). Relationships between politics, cities and architecture based on the examples of two Hungarian New Towns. Cities, 48, 99-105. https://doi.org/10.1016/j.cities.2015.06.007

[4] Bodnar, J. (2001). Fin de millenaire Budapest: Metamorphoses of Urban Life. Minneapolis: University of Minnesota Press.

[5] Arandjelovic, B., Vukmirovic, M., \& Samardzic, N. (2017). Belgrade: Imaging the future and creating a European metropolis. Cities, 63, 1-19. https://doi.org/10.1016/j.cities.2016.12.010

[6] Le Normand, B. (2009). Urban development in Belgrade 1945-1972. Informationen zur modernen Stadtgeschichte, 1, 60-69.

[7] Vujosevic, M., Zekovic, S., \& Maricic T. (2010). Postsocialist transition and spatial development of Serbia. Proceedings of WSEAS International Conference UPT'10 "Latest trends on Urban Planning and transportation", Corfu Island, Greece, 60-65.

[8] Doxiadis, C. A. (1963). Architecture in transition. New York, NY: Oxford University Press.

[9] Ibelings, H. (1998). Super modernism: Architecture in the Age of Globalization ( $1^{\text {st }}$ Ed.). New York, NY: NAI Publishers.

[10] Giddens, A. (1990). The Consequences of Modernity. Stanford, CT: Stanford University Press.

[11] Adam, R. (2008). Globalisation and architecture: The challenges of globalisation are relentlessly shaping architecture's relationship with society and culture. The Architectural Review 223(1332), 74-77.

[12] Vujovic, S. (1990). Ljudi i gradovi. Beograd: Filozofski fakultet. (in Serbian)

[13] Petrovic, M. (2009). Transformacija gradova: ka depolitizaciji urbanog pitanja. Beograd, Srbija: Institut za sociološka istraživanja Filozofskog fakulteta-Beogradu. (in Serbian)

[14] Fainstein, S. (2008). Mega-projects in New York, London and Amsterdam, International Journal of Urban and Regional Research, 32 (4), 768-785. https://doi.org/10.1111//.1468-2427.2008.00826.x

[15] Harvey, D. (1989). From Managerialism to Entrepreneurialism: The Transformation in Urban Governance in Late Capitalism, Geografiska Annaler. Series B, Human Geography, The Roots of Geographical Change: 1973 to the Present, 71 (1), 3-17. https://doi.org/10.1080/04353684.1989.11879583

[16] Chen, S. (2011). Common interest development and the changing roles of government and market in planning. Urban Studies, 48(16), 3599-3612. https://doi.org/10.1177/0042098010394687

[17] Anthonisz, S. \& Perry, C. (2015). Effective marketing of high-rise luxury condominiums in a middle-income country like Sri Lanka. Journal of Work-Applied Management, 7(1), 61-83. https://doi.org/10.1108/JWAM-10-2015-002

[18] Atkinson, R. \& Blandy, S. (2005). Introduction: International perspectives on the new enclavism and the rise of gated communities. Housing Studies, 20(2), 177-186. https://doi.org/10.1080/0267303042000331718

[19] Johnston, N. R. \& Reid, S. (2013). Multi-owned developments: a life cycle review of a developing research area. Property management, 31(5), 366-388. https://doi.org/10.1108/PM-01-2013-0003

[20] Bajic, T., Manic, B., \& Kovacevic, B. (2014). Social housing in Belgrade: practice in architecture and urban planning competitions (2003-2014). Архитектура и урбанизам, 39, 29-43. https://doi.org/10.5937/a-u0-6604

[21] Giofrè, F. \& Miletic, I. (2012). Between past and future: Social Housing in Serbia in the transitional process. TECHNE 04, 61-73. 


\section{Contact information:}

Danica STANKOVIĆ, Associate Professor

(Corresponding author)

Faculty of Civil Engineering and Architecture,

Aleksandra Medvedeva 14,

18000 Niš, Serbia

E-mail: danica.stankovic@gaf.ni.ac.rs

Milan TANIĆ, Associate Professor

Faculty of Civil Engineering and Architecture,

Aleksandra Medvedeva 14,

18000 Niš, Serbia

E-mail:milan.tanic@gaf.ni.ac.rs

Marko NIKOLIĆ, Assistant Professor

Faculty of Civil Engineering and Architecture, Aleksandra Medvedeva 14,

18000 Niš, Serbia

E-mail: marko.nikolic@gaf.ni.ac.rs

Miomir VASOV, Associate Professor

Faculty of Civil Engineering and Architecture, Aleksandra Medvedeva 14,

18000 Niš, Serbia

E-mail: miomir.vasov@gaf.ni.ac.rs

Branko TURNŠEK, Associate Professor

Faculty of Civil Engineering and Architecture,

Aleksandra Medvedeva 14,

18000 Niš, Serbia

E-mail: branko.turnsek@gaf.ni.ac.rs

Aleksandra CVETANOVIĆ, PhD Student

Faculty of Civil Engineering and Architecture,

Aleksandra Medvedeva 14,

18000 Niš, Serbia

E-mail: aleksandracv.arch@gmail.com

Aleksandra RANČIĆ, PhD Student

Faculty of Civil Engineering and Architecture,

Aleksandra Medvedeva 14,

18000 Niš, Serbia

E-mail: aleksandra.kostic1985@gmail.com 